\title{
Perubahan Karakteristik Fisikokimia Tepung Onggok Selama Proses Fermentasi Semi Padat Menggunakan Saccharomyces cerevisiae
}

\section{Changes in Physicochemical Characteristics of Cassava Bagasse Flour During Semi-Solid Fermentation Process Using Saccharomyces cerevisiae}

\section{Beni Hidayat*, M. Muslihudin, dan Syamsu Akmal}

Program Studi Teknologi Pangan

Jurusan Teknologi Pertanian, Politeknik Negeri Lampung

*E-mail : beni_lpg@polinela.ac.id

\begin{abstract}
Cassava bagasse is a by-product of tapioca industry whose use as food is relatively limited. The improvement of the cassava bagasse flour characteristics as a food ingredient can be done through a semi-solid fermentation process. The aim of this study was to examine the changes in physicochemical characteristics of cassava bagasse flour during the semi-solid fermentation process using Saccharomyces cerevisiae. The semi-solid fermentation process was carried out for 0 days (control), 1 day, 2 days, 3 days, 4 days, and 5 days. Observations of physicochemical characteristics include pasting characteristics, microstructure, water absorption index, and water solubility index. The results showed that the fermentation process had no effect on the gelatinization temperature but affected the viscosity of the cassava bagasse flour; during fermentation, liberation and erosion of the starch granule will be more intense occur, as well as an increase in water absorption index and water solubility index.
\end{abstract}

Keywords: Cassava Bagasse Flour, Physicochemical Characteristics, Saccharomyces cerevisiae

Disubmit : 12 Juni 2018, Diterima: 15 Juli 2018, Disetujui : 11 September 2018

\section{PENDAHULUAN}

Onggok merupakan produk samping industri tapioka yang penggunaannya sebagai bahan pangan relatif terbatas. Berdasarkan data produksi ubi kayu Indonesia Tahun 2015, produksi ubi kayu adalah sebesar 21.790.956 ton (BPS, 2016). Jika diasumsikan 90\% ubi kayu tersebut diolah menjadi tapioka (19.611.860 ton), dan dari 1 ton ubi kayu akan diperoleh 60\% onggok (FAO, 2001)maka akan dihasilkan sebanyak 11.767.116 ton onggok.

Mengingat karakteristik onggok yang semi padat dengan kadar air yang tinggi maka perbaikan karakteristik tepung onggok sebagai bahan pangan dapat dilakukan melalui proses fermentasi semi padat seperti yang dilaporkan oleh (Hidayat et al., 2018), (Olaoye et al., 2015), (Izah, Bassey and Ohimain, 2017), dan (Kaewwongsa et al., 2011) Hasil penelitian (Hidayat et al., 2018), menunjukkan bahwa melalui proses fermentasi semi padat selama 4 hari menggunakan Saccharomyces cerevisiae bentuk bubuk akan meningkatkan kandungan protein ( $0.92 \%$ menjadi $6.98 \%)$, meningkatkan derajat putih $(31.50 \%$ menjadi $52.70 \%$ ), meningkatkan skor aroma (4.50 menjadi 5.95), menurunkan kadar pati (55.36\% menjadi 46.69\%), menurunkan kandungan serat pangan (23.13\% menjadi $13.49 \%)$, menurunkan kandungan lemak $(0.95 \%$ 
menjadi $0.59 \%$ ), serta menurunkan kandungan asam sianida (30.52\% menjadi $8.87 \%$ ). Peningkatan kandungan protein dan penurunan kandungan asam sianida $(\mathrm{HCN})$ hingga ke tingkat aman untuk dikonsumsi yaitu sebesar 8.87 ppm menunjukkan bahwa proses fermentasi semi padat cukup potensial diaplikasikan untuk memperbaiki karakteristik tepung onggok dalam rangka penggunaannya sebagai bahan pangan. FAO/WHO merekomendasikan batas aman asupan sianida dari bahan pangan sebesar $10 \mathrm{mg} \mathrm{HCN} / \mathrm{kg}$ (Alimentarius, 1989)

Meskipun proses fermentasi padat mampu memperbaiki karakteristik kimia tepung onggok, diperlukan penelitian lebih lanjut untuk mengkaji perubahan karakteristik fisikokimia tepung onggok selama proses fermentasi semi-padat. Informasi perubahan karakteristik fisikokimia tepung onggok tersebut akan sangat menentukan aplikasi lebih lanjut tepung onggok terfermentasi sebagai bahan baku aneka produk pangan. Penelitian bertujuan mengkaji perubahan karakteristik fisikokimia tepung onggok selama proses fermentasi semi-padat meliputi karakteristik pasting, mikrostruktur, indeks penyerapan air, dan indeks kelarutan air.

\section{METODE PENELITIAN}

Penelitian dilakukan di Laboratorium Teknologi Hasil Pertanian Politeknik Negeri Lampung, Balai Besar Teknologi Pati Lampung, serta Laboratorium Terpadu dan Sentra Inovasi Teknologi Politeknik Negeri Lampung. Penelitian dilaksanakan pada Bulan Maret Hingga Juli 2018. Bahan utama penelitian adalah ubi kayu varietas kasetsart yang diperoleh dari petani ubi kayu di Desa Margomulyo, Kecamatan Jati Agung, Kabupaten Lampung Selatan. Alat utama yang digunakan pada pengujian sifat fisikokimia tepung onggok terfermentasi antara lain adalah Brabender viscograph tife Brabender GmbH \& Co.KG dan scanning electron microscope (SEM) tife SEM ZEISS EVO MA 10.

Penyiapan Onggok Segar. Penyiapan onggok segar dilakukan melalui tahapan sortasi, pengupasan ubi kayu metode abrasi, ditambahkan air 20 kali volume ubi kayu, dan dipress hingga air hasil pengepresan berwarna jernih. Onggok yang diperoleh selanjutnya direndam selama \pm 2 jam sambil sesekali diaduk, dan dipress kembali untuk memisahkan airnya.

Proses Fermentasi Onggok. Khamir Saccharomyces cerevisiae dalam bentuk bubuk sejumlah 2\% dicampur merata dengan onggok, dan dimasukkan kedalam toples plastik berlubang. Proses fermentasi dilakukan pada suhu kamar dengan lama sesuai perlakuan (0 hari, 1 hari, 2 hari, 3 hari, 4 hari, dan 5 hari).

Tabel 1. Kadar pati dan kadar serat pangan tepung onggok terfermentasi pada berbagai lama fermentasi

\begin{tabular}{lcc}
\hline Perlakuan & Kadar pati $(\% \mathrm{db})$ & Kadar serat pangan $(\% \mathrm{db})$ \\
\hline Lama fermentasi 0 hari & $53.29 \pm 1.34$ & $17.69 \pm 0.18$ \\
Lama fermentasi 1 hari & $52.28 \pm 0.07$ & $16.77 \pm 0.20$ \\
Lama fermentasi 2 hari & $50.76 \pm 0.94$ & $15.26 \pm 0.32$ \\
Lama fermentasi 3 hari & $48.68 \pm 0.99$ & $14.27 \pm 0.05$ \\
Lama fermentasi 4 hari & $46.69 \pm 0.98$ & $13.49 \pm 0.52$ \\
Lama fermentasi 5 hari & $44.53 \pm 1.36$ & $13.31 \pm 0.07$ \\
\hline
\end{tabular}

Pengujian sifat fisikokimia tepung onggok terfermentasi. Pengujian sifat fisikokimia meliputi karakteristik pasting, mikrostruktur, indeks penyerapan air, dan indeks kelarutan air. Pengujian karakteristik pasting dilakukan dengan metode brabender, mikrostruktur dengan metode scanning electron microscope (SEM), indeks penyerapan air dan indeks kelarutan air dengan metode gravimetri. Khusus untuk pengujian indeks penyerapan air dan indeks kelarutan air dilakukan dengan 3 kali ulangan dan data yang diperoleh disajikan dalam bentuk nilai rata-rata \pm standar deviasi (SD). Data indeks penyerapan air dan indeks kelarutan air diolah menggunakan anova (sidik ragam) dilanjutkan dengan uji BNT pada taraf nyata 1 dan 
5\%. Adapun karakteristik kimia tepung onggok terfermentasi meliputi kadar pati dan kadar serat pangan, disajikan pada Tabel 1.

\section{HASIL DAN PEMBAHASAN}

Karakteristik Pasting Tepung Onggok Termodifikasi. Hasil pengujian pada Tabel 2, menunjukkan bahwa peningkatan lama fermentasi hingga 5 hari akan menurunkan viskositas maksimum (183 BU menjadi $68 \mathrm{BU}$ ), viskositas awal pendinginan (152 BU menjadi $55 \mathrm{BU}$ ), viskositas akhir pendinginan (209 BU menjadi $63 \mathrm{BU}$ ), viskositas retrogradasi (202 BU menjadi $80 \mathrm{BU}$ ), dan viskositas balik (31 BU menjadi 13 BU). Hasil pengujian juga menunjukkan bahwa lama fermentasi tidak berpengaruh terhadap suhu gelatinisasi $\left(69.4^{\circ} \mathrm{C}\right.$ hingga $\left.71.9^{\circ} \mathrm{C}\right)$ dan suhu saat tercapai viskositas maksimum $\left(90.2^{\circ} \mathrm{C}\right.$ hingga $\left.93.3^{\circ} \mathrm{C}\right)$. Hal ini sejalan dengan hasil penelitian (Eduardo et al., 2013) yang melaporkan bahwa proses fermentasi dan metode pengeringan tidak berpengaruh terhadap karakteristik suhu gelatinisasi granula pati ubi kayu.

Penurunan viskositas maksimum tepung onggok sangat terkait dengan penurunan kandungan pati tepung onggok dengan semakin lamanya proses fermentasi yaitu dari $53.29 \%$ menjadi $44.53 \%$ (Tabel 1). Keterkaitan antara konsentrasi pati dengan viskositas pati juga dilaporkan oleh (Zaidul et al., 2007), yang menyatakan bahwa peningkatan viskositas pada produk tepung komposit gandum-kentang-ubi jalar-yam-pati ubi kayu berkaitan dengan peningkatan konsentrasi pati tepung komposit. Penurunan kandungan pati tepung onggok selama proses fermentasi berkaitan dengan penggunaan pati sebagai sumber nutrisi oleh Saccharomyces cerevisiae. Hal ini sesuai dengan pendapat (Yuliana et al., 2016) yang menyatakan bahwa pada proses fermentasi produk-produk tinggi pati, pati merupakan sumber nutrisi utama. Dibandingkan dengan tepung ubi kayu yang memiliki viskositas maksimum sebesar 900 BU (Hidayat et al., 2018) tepung onggok fermentasi memiliki viskositas maksimum yang lebih rendah (68 BU hingga $183 \mathrm{BU}$ ). Rendahnya nilai viskositas maksimum ini menunjukkan bahwa tepung onggok fermentasi memiliki kemampuan yang rendah untuk mengembang selama proses pemanasan (Marta et al., 2016).

Tabel 2. Karakteristik pasting tepung onggok terfermentasi pada berbagai lama fermentasi

\begin{tabular}{lccccccc}
\hline \multicolumn{1}{c}{ Perlakuan } & $\begin{array}{c}\text { SG } \\
\left({ }^{\circ} \mathrm{C}\right)\end{array}$ & $\begin{array}{c}\text { SVT } \\
\left({ }^{\circ} \mathrm{C}\right)\end{array}$ & $\begin{array}{c}\text { VM } \\
(\mathrm{BU})\end{array}$ & $\begin{array}{c}\text { VawP } \\
(\mathrm{BU})\end{array}$ & $\begin{array}{c}\text { VaKP } \\
(\mathrm{BU})\end{array}$ & $\begin{array}{c}\text { VR } \\
(\mathrm{BU})\end{array}$ & $\begin{array}{c}\text { VB } \\
(\mathrm{BU})\end{array}$ \\
\hline Lama fermentasi 0 hari A & 69.8 & 92.8 & 183 & 152 & 209 & 202 & 31 \\
Lama fermentasi 1 hari B & 70.1 & 92.9 & 183 & 150 & 204 & 196 & 33 \\
Lama fermentasi 2 hari D & 69.4 & 93.3 & 159 & 120 & 173 & 169 & 39 \\
Lama fermentasi 3 hari F & 70.8 & 93.3 & 124 & 105 & 151 & 148 & 19 \\
Lama fermentasi 4 hari E & 69.6 & 90.2 & 87 & 59 & 98 & 94 & 28 \\
Lama fermentasi 5 hari C & 71.9 & 93.1 & 68 & 55 & 63 & 80 & 13 \\
\hline
\end{tabular}

Keterangan :

SG = suhu gelatinisasi

SVT = suhu saat tercapai viskositas maksimum

$\mathrm{VM} \quad=$ viskositas maksimum

BU = brabender unit

$$
\begin{array}{ll}
\text { VawP } & =\text { viskositas awal pendinginan } \\
\text { VaKP } & =\text { viskositas akhir pendinginan } \\
\text { VB } & =\text { viskositas balik }
\end{array}
$$

Mikrostruktur Tepung Onggok Terfermentasi. Hasil penelitian pada Gambar 1, menunjukkan bahwa peningkatan lama fermentasi hingga 5 hari akan menyebabkan rusak dan terbukanya matriks serat yang menyelubungi kumpulan granula pati, terjadinya liberasi pati dari matriks serat, dilanjutkan dengan pemecahan granula pati. Pada Gambar 1, dapat dilihat bahwa pada lama fermentasi 0 hari (kontrol), sebagian besar granula pati tergabung dengan granula pati lainnya dan terselubung oleh matriks serat. Hal ini menunjukkan bahwa onggok yang nerupakan produk samping pati masih memiliki kandungan pati dan kandungan serat yang tinggi. Menurut (Raupp et al., 2004), onggok mengandung pati yang cukup tinggi yaitu sebesar $43,1 \% \mathrm{db}$ (dry basis), dan serat pangan dengan kandungan sebesar sebesar $47,1 \% \mathrm{db}$. 
Hidayat : Perubahan Karakteristik Fisikokimia Tepung Onggok Selama Proses Fermentasi Semi Padat...

Terselubungnya granula pati oleh matriks serat menyebabkan proses ekstraksi pati tidak mampu dilakukan secara sempurna dan masih menyisakan pati pada onggok. Menurut (Nurdjanah et al., 2016)serat pangan onggok tersusun dari pektin $(10,11 \%)$, hemiselulosa $(21,8 \%)$, dan selulosa $(6,31 \%)$.

Pada lama fermentasi 1 hari (Gambar 1), terlihat bahwa selubung matriks serat mulai terbuka dan granula pati mulai terbebaskan dari selubung matriks serat tersebut. Rusaknya struktur matriks serat berkaitan dengan proses hidrolisis serat oleh aktivitas Saccharomyces cerevisiae selama proses fermentasi yang ditunjukan oleh penurunan kandungan serat dari $17.69 \% \mathrm{db}$ menjadi $16.77 \% \mathrm{db}$ (Tabel 1). Hal ini sesuai dengan pendapat (Sriroth et al., 2000), bahwa matriks serat pada onggok dapat dirusak dengan metode enzimatis atau fisik. Rusaknya struktur matriks serat selama proses fermentasi juga dilaporkan oleh (Eduardo et al., 2013) pada proses fermentasi tepung ubi kayu. Rusaknya struktur serat oleh aktivitas Saccharomyces cerevisiae, menunjukkan bahwa selama proses fermentasi onggok sistem semi padatSaccharomyces cerevisiae selain menghasilkan enzim-enzim yang akan menghidrolisis pati juga menghasilkan enzim-enzim yang dapat menguraikan komponen serat
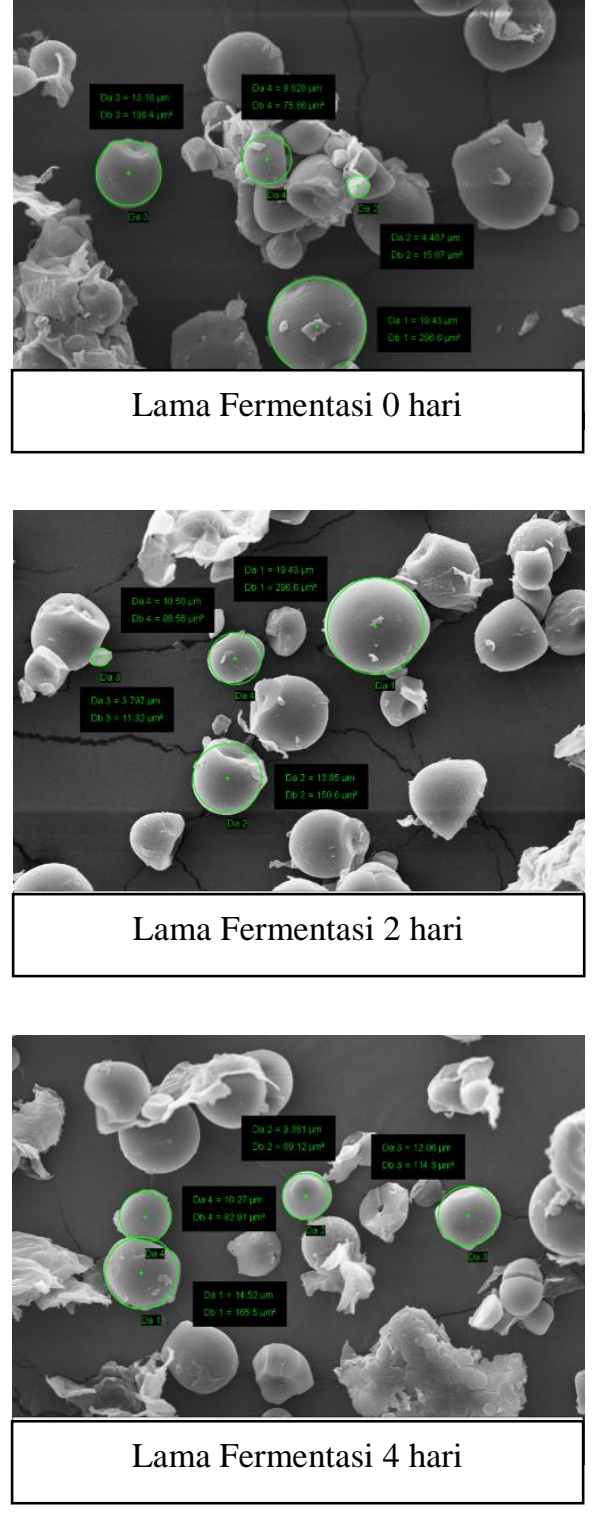
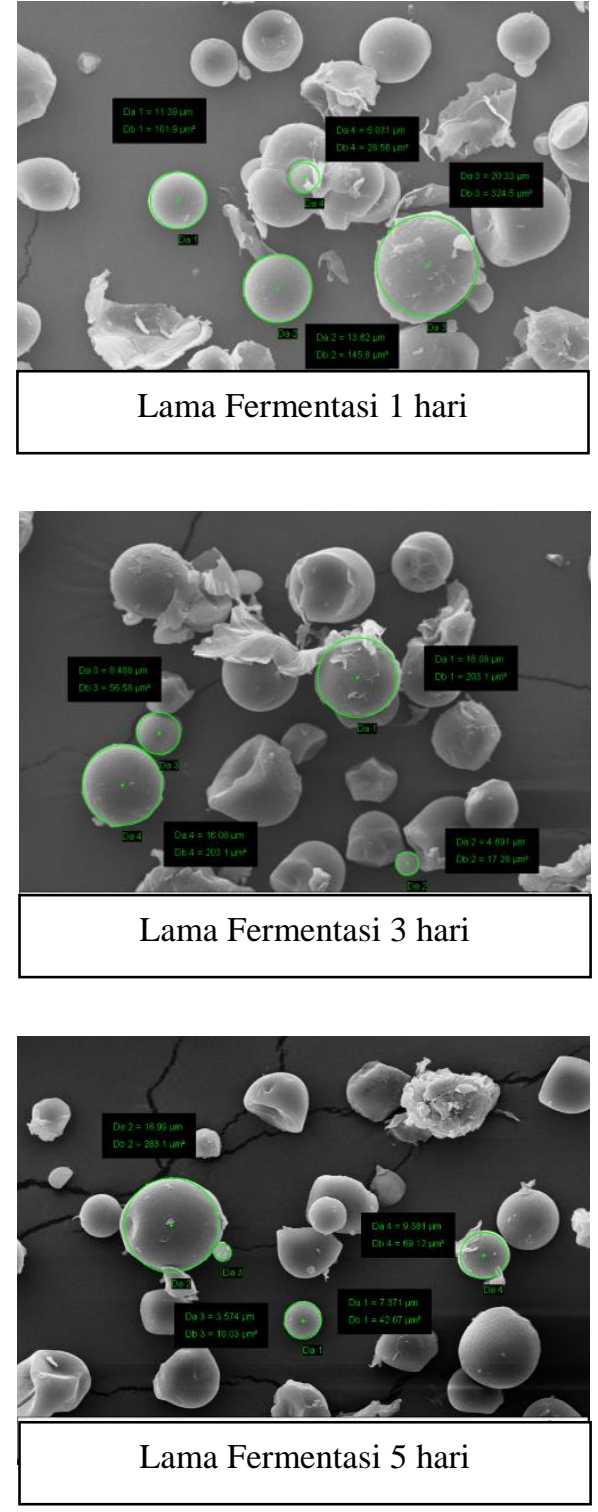

Gambar 1. Mikrostruktur tepung onggok terfermentasi pada berbagai lama fermentasi (metode scanning electron microscope) 
Hasil penelitian pada Gambar 1 juga menunjukkan bahwa selama proses fermentasi, granula pati tidak mengalami proses pengembangan yang ditunjukkan oleh ukuran granula pati yang tetap berkisar antara 3-18 mikron. Tidak terjadinya proses pengembangan granula pati selama proses semi padat berkaitan dengan kondisi kadar air yang terbatas dan pada akhir menyebabkan tidak adanya perubahan suhu gelatinisasi pati. Menurut (Medikasari et al., 2009), perubahan suhu gelatinisasi pati berkaitan dengan adanya proses pengembangan granula.

Fermentasi selanjutnya, 2 hingga 5 hari, menunjukkan bahwa granula pati yang terliberasi (keluar dari struktur matriks serat) mulai mengalami pemecahan menjadi granula-granula yang lebih kecil. Semakin lama fermentasi, maka pemecahan granula terjadi semakin intensif. Sejak lama fermentasi 2 hari, terlihat granula pati mulai tidak utuh, retak dan pecah menjadi granula-granula lebih kecil. Proses pemecahan granula pati sangat terkait dengan penggunaan pati sebagai sumber nutrisi utama oleh Saccharomyces cerevisiae yang ditunjukan oleh semakin menurunnya kadar pati selama proses fermentasi (Tabel 1). Proses liberasi granula pati dilanjutkan dengan penggunaannya sebagai sumber nutrisi yang berakibat pada penurunan kandungan pati juga terkait dengan semakin menurunnya viskositas dengan semakin lamanya proses fermentasi. Semakin intensifnya proses pemecahan granula dengan semakin lamanya proses fermentasi, juga dilaporkan oleh (Marcon et al., 2006) pada proses fermentasi pati asam.

Indeks Penyerapan Air, dan Indeks Kelarutan Air. Hasil penelitian pada Tabel 3, menunjukkan bahwa peningkatan lama fermentasi hingga 5 hari akan menurunkan indeks penyerapan air tetapi akan meningkatkan indeks kelarutan air tepung onggok terfermentasi. Penurunan indeks penyerapan air dengan semakin lamanya waktu fermentasi sangat terkait dengan penurunan kandungan pati selama proses fermentasi (Tabel 1). Semakin rendah kandungan pati suatu bahan pangan maka akan semakin rendah pula indeks penyerapan airnya. Hal lain yang akan menyebabkan perubahan karakteristik indeks penyerapan air adalah kondisi ikatan antar granula pati. Menurut (Aviara, et all, 2010), semakin lemah ikatan antar granula pati maka akan semakin tinggi kemampuan pati untuk menyerap air. Berdasarkan hasil penelitian pada Gambar 1, terlihat bahwa semakin lama proses fermentasi, maka ikatan antar granula pati akan semakin lemah. Hanya saja pengaruh pelemahan ikatan antar granula ini pengaruhnya terhadap karakteristik indeks penyerapan air lebih kecil dibandingkan pengaruh penurunan kandungan pati selama proses fermentasi. Selain akibat penurunan kandungan pati, penurunan indeks penyerapan air juga disebabkan oleh terhidrolisisnya pati menjadi komponen-komponen yang lebih sederhana (Yuliana et al., 2016; Erezka et al., 2018).

Peningkatan indeks kelarutan air tepung onggok terfermentasi dengan semakin lamanya waktu fermentasi disebabkan semakin intensifnya proses hidrolisis pati menjadi komponen dengan derajat polimerisasi rendah. Semakin lama fermentasi akan semakin tinggi jumlah komponen dengan derajat polimerisasi rendah yang akan mengakibatkan semakin meningkatnya indeks kelarutan air. (Yuliana et al., 2016), melaporkan bahwa peningkatan indeks kelarutan air terutama disebabkan oleh terhidrolisnya pati menjadi polimer-polimer yang lebih sederhana yang bersifat larut air.

Tabel 3. Indeks penyerapan air dan indeks kelarutan air tepung onggok terfermentasi pada berbagai lama fermentasi

\begin{tabular}{ccc}
\hline Perlakuan & Indeks Penyerapan Air $(\mathrm{g} / \mathrm{g})$ & Indeks Kelarutan Air $(\mathrm{g} / \mathrm{ml})$ \\
\hline Lama fermentasi 0 hari & 25.7903 & 0.0014 \\
Lama fermentasi 1 hari & 25.0319 & 0,0053 \\
Lama fermentasi 2 hari & 24.1900 & 0.0095 \\
Lama fermentasi 3 hari & 24.1516 & 0,0126 \\
Lama fermentasi 4 hari & 22.8494 & 0.0138 \\
Lama fermentasi 5 hari & 21.8254 & 0.0187 \\
\hline
\end{tabular}


Hidayat : Perubahan Karakteristik Fisikokimia Tepung Onggok Selama Proses Fermentasi Semi Padat...

\section{KESIMPULAN}

Hasil penelitian menunjukkan bahwa lama proses fermentasi tidak berpengaruh terhadap suhu gelatinisasi tetapi berpengaruh terhadap viskositas tepung onggok fermentasi. Semakin lama proses fermentasi maka granula pati akan mengalami liberasi dari matriks serat dan pemecahan granula yang makin intens, serta terjadi penurunan indeks penyerapan air $(25.79 \mathrm{~g} / \mathrm{g}$ menjadi $21.83 \mathrm{~g} / \mathrm{g})$ dan peningkatan indeks kelarutan air $(0.0014 \mathrm{~g} / \mathrm{ml}$ menjadi $0.0187 \mathrm{~g} / \mathrm{ml})$.

\section{UCAPAN TERIMA KASIH}

Penulis mengucapkan terima kasih kepada Direktorat Riset dan Pengabdian Masyarakat, Kementerian Riset, Teknologi, dan Pendidikan Tinggi, atas pendanaan kegiatan ini melalui skim Penelitian Pengembangan Unggulan Perguruan Tinggi (PPUPT) tahun 2018.

\section{DAFTAR PUSTAKA}

Alimentarius, C. (1989) Codex Standard for Edible Cassava Flour Codex Aliment. Comm. FAO/OMS).

Aviara, N. A. ., Igbeka, J. C. . and Nwokocha, L. M. (2010) 'Effect of drying temperature on physicochemical properties of cassava starch', Int. Agrophys, 24, pp. 219-225.

BPS (2016) Data produksi ubi kayu Indonesia.

Eduardo, M. et al. (2013) 'Effect of Cassava Flour Characteristics on Properties of Cassava-Wheat-Maize Composite Bread Types', International Journal of Food Science, 2013.

Erezka, V. C. et al. (2018) 'Karakteristik Pati Ganyong Termodifikasi Melalui Radiasi UV-C (Ultraviolet C) dan Hidrolisis Asam Laktat', Jurnal Teknologi Pertanian Andalas, 22(2), pp. 139-149.

FAO (2001) Impact of Cassava Processing on the Environment, in Strategic environmental assessment, FAO Corporate Document Repository. Available at: http://www.fao.org/ (Accessed: 1 April 2017).

Hidayat, B. et al. (2018) 'Improvement of Cassava Bagasse Flour Characteristics To Increase Their Potential Use as Food', in International Conference on Biomass.

Izah, S. C., Bassey, S. E. and Ohimain, E. I. (2017) 'Cyanide and Macro-Nutrients Content of Saccharomyces cerevisiae Biomass Cultured in Cassava Mill Effluents', International Journal of Microbiology and Biotechnology, 2(4), pp. 176-180.

Kaewwongsa, W. et al. (2011) 'Protein Enrichment of Cassava Pulp Fermentation by Saccharomyces cerevisiae.', Journal of Animal and Veterinary Advances, 10(18), pp. 1434-2440.

Marcon, M. J. A. et al. (2006) 'The Effect of Fermentation on Cassava Starch Microstructure', Journal of Food Process Engineering, 29, pp. 362-372.

Marta, H. et al. (2016) 'Sifat Fungsional dan Amilografi Pati Millet Putih. Jurnal Aplikasi Teknologi Pangan', Jurnal Aplikasi Teknologi Pangan, 3(5), pp. 76-84.

Medikasari et al. (2009) 'Sifat Amilografi Pasta Pati Sukun Termodifikasi Menggunakan Sodium Tripolifosfat.', Jurnal Teknologi Industri dan Hasil Pertanian, 14(2), pp. 173-177.

N, Y. et al. (2016) 'Improving Properties of Sweet Potato Composite Flour: Influence of Lactic Fermentation', in AIP Conference Proceedings.

Olaoye, O. A. et al. (2015) 'Evaluation of quality attributes of cassava product (gari) produced at varying length of fermentation', American Journal of Agricultural Science, 2(1), pp. 1-7. 
Raupp, D. S. et al. (2004) 'Digestive and Functional Properties of a Partially Hydrolyzed Cassava Solid Waste', Sci. Agric. (Piracicaba, Braz.), 61(3), pp. 286-291.

Sriroth, K. et al. (2000) 'Processing of cassava waste for improved biomass utilization.', Bioresource Technology, 71, pp. 63-69.

Zaidul, I. S. M. et al. (2007) 'RVA analysis of mixtures of wheat flour and potato, sweet potato, yam, and cassava starches', Carbohydrate Polymers, 69, pp. 784-791. 